\title{
Drug-induced reverse ocular dipping
}

\author{
Naoyuki Kitagawa, Michio Sakurai
}

Department of Neurology, Kohsei Chuo General Hospital, Tokyo, Japan

\section{Correspondence to}

Dr Naoyuki Kitagawa knaoyuki.neurology@gmail. com

Accepted 9 September 2014

\section{CrossMark}

To cite: Kitagawa $\mathrm{N}$ Sakurai M. BMJ Case Rep Published online: [please include Day Month Year] doi:10.1136/bcr-2014206951

\section{DESCRIPTION}

A 19-year-old male patient, who had undergone laminectomy for lumbar disc herniation the previous day, reported involuntary upward movement of his eyes. The eyes exhibited conjugate upward movement, followed by a brief tonic phase, and rapid downward movement to the primary position. These cycles were repeated at irregular intervals (video 1). He was awake and could respond to simple commands and explain his symptoms in his own words. There were no neurological abnormalities except abnormal eye movement. After the surgery, droperidol and fentanyl had been administered by continuous infusion for pain relief. The abnormal eye movements resolved within $2-3 \mathrm{~h}$ after withdrawal of these drugs (video 1). Brain CT and blood examination revealed no abnormalities.

Ocular bobbing is the best known abnormal spontaneous eye movement, and several variants of these movements have been described according to the direction and speed of the drifts. Reverse ocular dipping is one of these variants, first described by Mehler. ${ }^{1}$ Abnormal spontaneous eye movements have been shown to be associated with various clinical settings and a few cases of

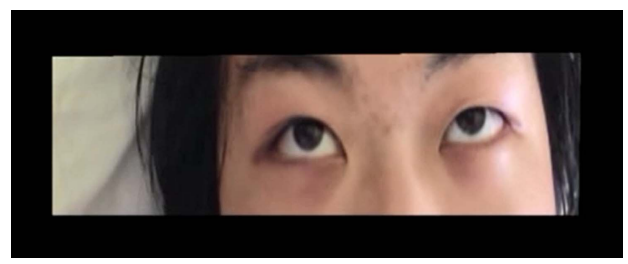

Video 1 (a) The eyes exhibited conjugate upward movement, followed by a brief tonic phase and rapid downward movement to the primary position. These cycles were repeated at irregular intervals. (b) Ocular dipping was resolved after withdrawal of droperidol and fentanyl. drug-induced abnormal eye movement have been reported..$^{12}$ It has been reported that fentanyl can cause transient disturbance of eye fixation with downbeat nystagmus in normal patients. ${ }^{3}$ Opioid receptors are located in the medial vestibular nucleus. The activation of opioid receptors in the medial vestibular nucleus inhibits the tonic discharge of these cells, which may cause eye fixation abnormalities. ${ }^{3}$ In our case, fentanyl may have induced reverse ocular dipping by a similar mechanism.

\section{Learning points}

- Reverse ocular dipping is a rare abnormal eye movement, which could be caused by some drugs.

- Opioid may cause eye fixation abnormalities and it could induce reverse ocular dipping.

Contributors NK and MS contributed in the drafting/revising the manuscript, study concept or design, analysis or interpretation of data and gave final approval. MS was involved in the acquisition of data.

Competing interests None.

Patient consent Obtained.

Provenance and peer review Not commissioned; externally peer reviewed.

\section{REFERENCES}

1 Mehler MF. The clinical spectrum of ocular bobbing and ocular dipping. J Neurol Neurosurg Psychiatry 1988;51:725-7.

2 Lennox G. Reverse ocular bobbing due to combined phenothiazine and benzodiazepine poisoning. I Neurol Neurosurg Psychiatry 1993;56:1136-7.

3 Rottach KG, Wohlgemuth WA, Dzaja AE, et al. Effects of intravenous opioids on eye movements in humans: possible mechanisms. J Neurol 2002:249:1200-5.

Copyright 2014 BMJ Publishing Group. All rights reserved. For permission to reuse any of this content visit http://group.bmj.com/group/rights-licensing/permissions.

BMJ Case Report Fellows may re-use this article for personal use and teaching without any further permission.

Become a Fellow of BMJ Case Reports today and you can:

- Submit as many cases as you like

- Enjoy fast sympathetic peer review and rapid publication of accepted articles

- Access all the published articles

- Re-use any of the published material for personal use and teaching without further permission

For information on Institutional Fellowships contact consortiasales@bmjgroup.com

Visit casereports.bmj.com for more articles like this and to become a Fellow 